\title{
KAJIAN DISTRIBUSI PANGAN POKOK BERAS DI KABUPATEN KEPULAUAN TALAUD
}

\author{
Eyverson Ruauw
}

\begin{abstract}
This study aims to determine the various models of distribution channels / staple food marketing and analyze the performance of the market of each channel of distribution / marketing of staple food to the people in Talaud Islands District. Primary data were obtained through direct observation in the field and in-depth interviews (depth) by using a list of questions (questionnaire) which had been prepared in advance to the institutions of marketing / distribution of food. Determination of the respondents in this study was conducted with a purposive sampling method and method snowbow of respondents key (key Pearson) of any marketing agencies. The results showed that the distribution of milled rice in the District of Talaud Islands only one pattern involving several marketing agencies, namely the village traders, wholesalers and retailers of Manado city in town Lirung Talaud Islands, while for rice packaging of Surabaya, the distribution includes agencies marketing Mananado local distributor, wholesaler in the city of Manado and retailers in town Lirung Talaud Islands. Also the results of the study showed that the total marketing margin is formed on the pattern of distribution channels milled rice food staples in Talaud Islands amounted to Rp2.500,00 per $\mathrm{kg}$, with a total marketing costs amounted to Rp413 per $\mathrm{kg}$, while for rice packaging, total marketing margin formed on the pattern of distribution channels staple food rice krmasan in District Talaud Islands is Rp 3.500,00 per $\mathrm{kg}$, with a total marketing costs Rp454 per $\mathrm{kg}$. The amount of the farmer's share of the milled rice marketing in District of Talaud Islands amounted to $73.68 \%$, where the farm-gate price of Rp7,000 per $\mathrm{kg}$ and prices at the consumer level of $R p 9,500$ per $\mathrm{kg}$. The ratio of cost advantages in marketing agency traders village is very large compared to the traders in the city of Manado and retailers in the City Lirung. Cost benefit ratio was lowest in the large trader marketing agencies in the city of Manado.
\end{abstract}

Keywords: Distribution, Rice

\begin{abstract}
ABSTRAK
Penelitian ini bertujuan untuk mengetahui beragam model saluran distribusi/pemasaran pangan pokok serta menganalisis keragaan pasar dari setiap saluran distribusi/pemasaran pangan pokok kepada masyarakat di Kabupaten Kepulauan Talaud. Data primer diperoleh melalui hasil pengamatan langsung di lapangan dan wawancara secara mendalam (indepth) dengan menggunakan daftar pertanyaan (kuisioner) yang telah disiapkan sebelumnya kepada lembaga-lembaga pemasaran/distribusi pangan. Penentuan responden pada penelitian ini dilakukan dengan metode purposive sampling dan metode snowbow dari responden kunci (key pearson) dari setiap lembaga pemasaran. Hasil penelitian menunjukkan bahwa distribusi beras giling di Kabupaten kepulauan Talaud hanya satu pola yang melibatkan beberapa lembaga pemasaran, yaitu pedagang pengumpul desa, pedagang besar di kota Manado dan pedagang pengecer di kota Lirung Kabupaten Kepulauan Talaud, sedangkan untuk beras kemasan dari Surabaya, distribusi melibatkan lembaga pemasaran distributor di kota Mananado, pedagang besar di kota Manado dan pedagang pengecer di kota Lirung
\end{abstract}


Kabupaten Kepulauan Talaud. Juga hasil penelitian menunjukan bahwa total marjin pemasaran yang terbentuk pada pola saluran distribusi bahan pokok pangan beras giling di Kabupaten Kepulauan Talaud adalah sebesar Rp 2500,00 per kg, dengan total biaya pemasaran sebesar Rp413 per kg, sedangkan untuk untuk beras kemasan, total marjin pemasaran yang terbentuk pada pola saluran distribusi bahan pokok pangan beras krmasan di Kabupaten Kepulauan Talaud adalah sebesar Rp $3.500,00$ per kg, dengan total biaya pemasaran sebesar Rp 454 per kg. Besarnya farmer's share pada pemasaran beras giling di Kabupaten Kepulauan Talaud adalah sebesar 73,68\%, dimana harga di tingkat petani sebesar Rp7.000 per kg dan harga di tingkat konsumen sebesar Rp9.500 per kg. Rasio keuntungan biaya pada lembaga pemasaran pedagang pengumpul desa sangat besar dibandingkan pada pedagang pengumpul di Kota Manado dan pedagang pengecer di Kota Lirung. Rasio keuntungan biaya terendah terjadi pada lembaga pemasaran pedagang besar di Kota Manado.

Kata- kunci: distribusi, beras

\section{PENDAHULUAN}

\section{Latar Belakang}

Pembangunan pertanian nasional bertujuan untuk mengatasi kekurangan pangan dalam jumlah dan mutu selain untuk memperkuat sektor industri, memperbesar peranannya dalam memperoleh devisa, menaikkan dan meratakan pendapatan, memperluas kesempatan kerja dan sekaligus melestarikan sumberdaya alam pertanian.

Ketahanan pangan menjadi salah satu prioritas dalam pembangunan nasional. Ada tiga alasan utama yang melandasi adanya kesadaran dari semua komponen bangsa atas pentingnya ketahanan pangan yaitu: (i) akses atas pangan yang cukup dan bergizi bagi setiap penduduk merupakan salah satu pemenuhan hak azasi manusia; (ii) konsumsi pangan dan gizi yang cukup merupakan basis bagi pembentukan sumberdaya manusia yang berkualitas; (iii) ketahanan pangan merupakan basis bagi ketahanan ekonomi, bahkan bagi ketahanan nasional suatu negara berdaulat.

Ketahanan pangan nasional salah satunya dicirikan dengan adanya ketersediaan pangan yang cukup secara makro namun demikian masih ada beberapa daerah dimana masyarakatnya tidak mampu mengakses pangan yang cukup. Hal ini disebabkan karena kondisi wilayahnya miskin ataupun pendapatan mereka yang tidak mencukupi untuk memperoleh akses terhadap pangan.

Di sisi lain melihat luasnya wilayah Indonesia dimana wilayah sentra produksi pertanian khususnya padi dan jagung berada pada topografi yang beragam, memiliki ketersediaan sarana prasarana untuk mendukung sektor tersebut (produksi, pengolahan, penyimpanan) sangat bervariasi, waktu panen yang tidak bersamaan pada beberapa wilayah, dan iklim yang kurang mendukung pada saat tanam maupun panen raya, sehingga petani, kelompok tani (Poktan) maupun Gabungan Kelompok Tani (Gapoktan) selalu dihadapkan pada berbagai masalah antara lain: (i) keterbatasan modal usaha untuk melakukan kegiatan pengolahan, penyimpanan, pendistribusian/pemasaran setelah panen; (ii) memiliki posisi tawar petani yang rendah pada saat panen raya yang bersamaan dengan datangnya hujan, sehingga petani terpaksa menjual produknya dengan harga rendah kepada para pelepas uang (pedagang perantara); (iii) keterbatasan akses pangan (beras) untuk dikonsumsi saat mereka menghadapi paceklik yang disebabkan karena tidak memiliki cadangan pangan yang cukup. Dampak dari ketidakberdayaan petani, Poktan dan Gapoktan tersebut dalam mengolah, menyimpan dan 
mendistribusikan/memasarkan

hasil

produksinya dapat menyebabkan:

ketidakstabilan harga untuk komoditas gabah/beras dan jagung di wilayah sentra produksi pertanian pada saat terjadi panen raya, dan (ii) kekurangan pangan (beras) yang dapat dikonsumsi pada saat mereka menghadapi musim paceklik.

Distribusi pangan merupakan salah satu subsistem ketahanan pangan yang peranannya sangat strategis, apabila tidak dapat terselenggara secara baik dan lancar, bahan pangan yang dibutuhkan masyarakat tidak akan terpenuhi. Distribusi pangan ini diharapkan dapat terlaksana secara efektif, efisien dan merata di setiap lokasi berlangsungnya transaksi bahan pangan kebutuhan masyarakat. Gangguan distribusi pangan ini berdampak terhadap kelangkaan bahan pangan dan kenaikan harga pangan serta berpengaruh terhadap rendahnya akses pangan masyarakat karena daya beli bahan pangan menjadi menurun. Distribusi pangan adalah tersedianya pangan dan pasokan pangan secara merata sepanjang waktu baik jumlah, mutu, aman dan keragamannya untuk memenuhi kebutuhan pangan masyarakat, sedangkanakses pangan adalah kemampuan rumah tangga untuk dapat menjangkau/mendapatkan pemenuhan kebutuhan pangan sepanjang waktu baik jumlah, mutu, aman, keragaman untuk menunjang hidup yang aktif, sehat dan produktif.Masalah pangan adalah keadaan kelebihan pangan, kekurangan pangan dan/atau ketidakmampuan rumah tangga dalam memenuhi kebutuhan pangan. Masih adanya penduduk miskin, daerah rawan pangan, produksi pangan dihasilkan tidak merata antar wilayah dan sepanjang waktu, potensi SDA yang berbeda di masing-masing daerah akan berpengaruh terhadap distribusi dan pasokan bahan pangan. Kondisi ini, pada akhirnya akses pangan bagi setiap individu rumah tangga akan semakin menjadi rendah apabila ketersediaan pangan setempat terbatas, pasar tidak tersedia, transportasi terbatas, pendapatan rendah, pendidikan terbatas, pengangguran tinggi, budaya setempat belum memadai. Oleh sebab itu, peranan distribusi pangan yang terjangkau dan merata sepanjang waktu kiranya akan berpengaruh terhadap peningkatan akses pangan bagi setiap rumah tangga di dalam memenuhi kecukupan pangannya.

Dalam UU No. 18/2012 tentang Pangan disebutkan bahwa ketahanan pangan adalah kondisi terpenuhinya Pangan bagi negara sampai dengan perseorangan, yang tercermin dari tersedianya Pangan yang cukup, baik jumlah maupun mutunya, aman, beragam, bergizi, merata, dan terjangkau serta tidak bertentangan dengan agama, keyakinan, dan budaya masyarakat, untuk dapat hidup sehat, aktif, dan produktif secara berkelanjutan.

Dengan demikian, ketahanan pangan dihasilkan oleh suatu sistem ketahanan pangan yang terdiri tiga subsistem, yaitu: ketersediaan pangan dalam jumlah dan jenis yang cukup untuk seluruh masyarakat, (2) distribusi pangan yang lancar dan merata, dan (3) keterjangkauan pangan setiap individu yang memenuhi kecukupan gizi dan kaidah kesehatan. Permasalahan dalam mencapai ketahanan pangan adalah ketidakseimbangan antara ketersediaan dengan keterjangkauan. Masalah ketersediaan disebabkan karena produksi berbagai jenis pangan tidak dapat dihasilkan di semua wilayah dan tidak dapat dihasilkan setiap saat dibutuhkan. Masalah produksi yang hanya terjadi di wilayah tertentu dan pada waktu-waktu tertentu, mengakibatkan konsentrasi ketersediaan di sentra-sentra produksi dan pada masa-masa panen.

Karena pentingnya distribusi pangan kepada masyarakat maka perlu dilakukan penelitian Kajian Distribusi Pangan Pokok Beras di Kabupaten Kepulauan Talaud.

\section{Tujuan dan Manfaat Penelitian}

Penelitian ini bertujuan untuk:

1. Mengetahui beragam model saluran distribusi/pemasaran pangan pokok kepada masyarakat di Kabupaten Kepulauan Talaud.

2. Menganalisis keragaan pasar (margin pemasaran, farmer's share dan rasio 
keuntungan biaya) dari setiap saluran distribusi/pemasaran pangan pokok kepada masyarakat di Kabupaten Kepulauan Talaud.

Hasil penelitian ini dapat menjadi dasar bagi pemerintah untuk mendorong kelancaran distribusi pangan masyarakat yang merata dan terjangkau di Kabupaten Kepulauan Talaud.

\section{TINJAUAN PUSTAKA}

\section{Konsep Pemasaran/Distribusi}

Pada awalnya konsep utama pemasaran yaitu pasar, yang diartikan sebagai tempat pertemuan antara penjual dan pembeli untuk mempertukarkan barang-barang. Pengertian pasar yang sering disarankan oleh para ahli ekonomi adalah tempat dimana terjadi interaksi antara penawaran dan permintaan produk (barang dan atau jasa), terjadi transaksi dan kesepakatan nilai, jumlah, spesifikasi produk, cara pengiriman, penerimaan dan pembayaran serta tempat terjadinya pemindahan kepemilikan barang atau jasa.

Pemasaran pertanian tidak terlepas dari konsep pasar, pemasaran dan pertanian. Pasar awalnya mengacu pada suatu geografis tempat transaksi berlangsung, namun pada perkembangan selanjutnya definisi tersebut sudah tidak sesuai lagi, terutama dengan berkembangnya teknologi informasi. Perkembangan teknologi informasi (telepon, internet dll) memungkinkan transaksi dapat dilakukan tanpa melalui kontak langsung antara penjual dengan pembeli. Kohls andUhl (1985) mendefinisikan pasar sebagai sebuah arena untuk mengatur dan menfasilitasi aktifitas bisnis serta untuk menjawab pertanyaanpertanyaan dasar ekonomi mengenai: produk apa yang dihasilkan, berapa banyak diproduksi, bagaimana cara memproduksi, dan bagaimana produk didistribusikan. Sedangkan menurut Cochrane dalam Dahl and Hammond, (1977), secara garis besar pasar merupakan sejumlah lingkungan atau tempat, dimana (1) kekuatan permintaan dan penawaran saling bertemu, (2) terbentuk harga serta perubahan harga terjadi, (3) terjadinya perpindahan kepemilikan sejumlah barang dan jasa, dan (4) beberapa susunan fisik dan institusi. Sudiyono (2002), mendefinisikan pasar sebagai tempat terjadinya pemenuhan kebutuhan dan keinginan dengan menggunakan alat pemuas yang berupa barang atau jasa, dimana terjadi pemindahan hak milik antara penjual dan pembeli. Secara umum pemasaran dianggap sebagai proses aliran barang yang terjadi dalam pasar, dari produsen sampai kepada konsumen akhir. Sedangkan pemasaran pertanian adalah proses aliran komoditi yang disertai perpindahan hak milik dan penciptaan guna waktu, tempat dan bentuk yang dilakukan oleh lembaga-lembaga pemasaran dengan melaksanakan satu atau lebih fungsi-fungsi pemasaran.

Kotler (2002), menyatakan bahwa pemasaran adalah suatu proses sosial yang didalammya individu dan kelompok mendapatkan apa yang mereka butuhkan dan inginkan dengan menciptakan, menawarkan dan secara bebas mempertukarkan produk yang bernilai dengan pihak lain. Produk tersebut diciptakan untuk memuaskan kebutuhan atau keinginan manusia, sehingga terjadi proses pertukaran untuk mendapatkan produk yang diinginkan atau kebutuhan usaha dari tangan produsen ke tangan konsumen. Konsep pemasaran berdiri diatas empat pilar, yaitu : pasar sasaran, kebutuhan pelanggan, pemasaran terpadu, dan kemampuan menghasilkan laba. Pemasaran merupakan salah satu fungsi bisnis yang menghasilkan penerimaan bagi produsen maupun konsumen. Said dan Intan (2004), mendefinisikan pemasaran sebagai sejumlah kegiatan bisnis yang ditujukan untuk memberi kepuasan dari barang atau jasa yang dipertukarkan kepada konsumen atau pemakai dalam bidang pertanian, baik input maupun produk pertanian. Sedangkan menurut Limbong dan Sitorus (1987), pemasaran adalah suatu rangkaian kegiatan yang terjadi dalam proses mengalirkan barang dan jasa dari sentra produksi ke sentra konsumsi guna memenuhi kebutuhan dan memberikan keuntungan bagi produsen. Konsep ini menunjukkan bahwa 
peranan pemasaran sangat penting dalam rangka meningkatkan nilai guna bentuk, nilai guna waktu, nilai guna tempat dan nilai guna hak milik dari suatu barang dan jasa secara umum serta pada komoditas pertanian.

Menurut Dahl and Hammond (1977), pemasaran merupakan suatu rangkaian fungsi dari lembaga pemasaran yang dibutuhkan untuk menggerakkan produk atau input dari titik produksi ke konsumen akhir. Dengan demikian, pemasaran adalah suatu kegiatan yang produktif karena memberikan nilai tambah dan menghasilkan berbagai kegunaan waktu, tempat, milik dan bentuk.

\section{Lembaga dan Saluran Pemasaran}

Said dan Intan (2004), menjelaskan bahwa peranan lembaga pemasaran dan distribusi menjadi ujung tombak keberhasilan pengembangan agribisnis, karena fungsinya sebagai fasilitator yang menghubungkan antara deficit units (konsumen pengguna yang membutuhkan produk) dan surplus units (produsen yang menghasilkan produk). Lembaga pemasaran dan distribusi juga memegang peranan penting dalam memperkuat integrasi antar subsistem dalam sistem agribisnis. Dengan demikian, pengembangan agribisnis yang terpadu harus dapat juga memperkuat peranan serta memberdayakan lembaga pemasaran dan distribusi secara efektif dan efisien. Pembinaan terhadap lembaga pemasaran dan distribusi sangat diperlukan, karena serangkaian aktivitasnya menjadi penentu utama besarnya marjin antara harga di tingkat produsen dan harga di tingkat konsumen. Salah satu ukuran distribusi yang efisien adalah rendahnya marjin antara harga produsen dan harga konsumen, namun tidak berarti lembaga pemasaran dan distribusi tersebut tidak mendapatkan untung, tetapi lebih pada upaya pembagian yang adil dari semua nilai tambah yang tercipta dalam suatu sistem komoditas kepada setiap pelaku yang terlibat.

Saluran pemasaran adalah serangkaian organisasi yang saling tergantung yang terlibat dalam proses untuk menjadikan produk atau jasa siap untuk digunakan atau dikonsumsi.
Saluran pemasaran melaksanakan tugas memindahkan barang dari produsen ke konsumen. Hal itu mengatasi kesenjangan waktu, tempat dan kepemilikan yang memisahkan barang dan jasa dari orang-orang yang membutuhkan atau menginginkannya (Kotler, 2002).

Said dan Intan (2004), menyatakan bahwa keberadaan kelembagaan pendukung pengembangan agribisnis nasional penting untuk menciptakan agribisnis Indonesia yang tangguh dan kompetitif. Lembaga-lembaga pendukung tersebut sangat menentukan dalam upaya menjamin terciptanya integrasi agribisnis dalam mewujudkan tujuan pengembangan agribisnis. Beberapa lembaga pendukung pengembangan agribisnis Indonesia adalah : pemerintah, lembaga pembiayaan, lembaga pemasaran dan distribusi, koperasi, lembaga pendidikan formal dan informal, lembaga penyuluhan pertanian, serta lembaga penjamin dan penanggungan resiko.

Menurut Limbong dan Sitorus (1987), sebagian besar produsen tidak menjual barang mereka langsung kepada pemakai akhir. Antara produsen dan pemakai akhir terdapat satu atau beberapa saluran pemasaran, yaitu serangkaian perantara pemasaran yang melaksanakan berbagai fungsi. Keputusan saluran pemasaran merupakan salah satu keputusan paling rumit dan menantang yang dihadapi produsen. Saluran yang dipilih sangat mempengaruhi semua keputusan pemasaran lain.

\section{Fungsi-fungsi Pemasaran}

Proses penyaluran barang dan atau jasa dari produsen ke tangan konsumen emerlukan berbagai kegiatan fungsional pemasaran yang ditujukan untuk memperlancar proses penyaluran barang dan atau jasa secara efektif dan efisien, untuk memenuhi kebutuhan dan keinginan konsumen. Kegiatan fungsional tersebut disebut sebagai fungsi-fungsi pemasaran. Fungsi-fungsi pemasaran dilakukan oleh lembaga-lembaga pemasaran yang terkait atau terlibat dalam proses pemasaran suatu komoditas, dan membentuk rantai pemasaran atau sering disebut sebagai sistem pemasaran. 
Aliran produk pertanian dari produsen sampai ke konsumen disertai dengan peningkatan nilai guna komoditi pertanian tersebut. Peningkatan nilai guna ini terwujud apabila terdapat lembaga-lembaga pemasaran yang melaksanakan fungsi-fungsi pemasaran. Pada umumnya fungsi-fungsi pemasaran yang dilaksanakan oleh lembaga-lembaga pemasaran adalah fungsi pertukaran, fungsi fisik dan fungsi fasilitas.

Said dan Intan (2004), menyatakan bahwa fungsi-fungsi pemasaran dapat didefinisikan sebagai serangkaian kegiatan fungsional yang dilakukan oleh lembagalembaga pemasaran, baik aktivitas proses fisik maupun aktivitas jasa, yang ditujukan untuk memberikan kepuasan kepada konsumen sesuai dengan kebutuhan dan keinginannya melalui penciptaan atau penambahan kegunaan bentuk, waktu, tempat, dan kepemilikan terhadap suatu produk. Fungsi-fungsi pemasaran ini diklasifikasikan menjadi tiga, yaitu:

1) Fungsi Pertukaran, meliputi:fungsi pembelian dan fungsi penjualan.

2) Fungsi Fisik Pemasaran, meliputi: fungsi penyimpanan, fungsi pengangkutan, dan fungsi pengolahan.

3) Fungsi Fasilitas Pemasaran, meliputi: fungsi standarisasi dan penggolongan produk, fungsi pembiayaan, fungsi penanggungan resiko, serta fungsi penyediaan informasi pasar.

\section{Keragaan Pasar}

Dahl and Hammond (1977), mengemukakan bahwa keragaan pasar merupakan akibat dari keadaan struktur dan perilaku pasar dalam kenyataan sehari-hari yang ditunjukkan dengan variabel harga, biaya, dan volume produksi dari output yang pada akhirnya akan memberikan penilaian baik atau tidaknya suatu sistem tataniaga. Deskripsi dari keragaan pasar dapat dilihat dari indikator: (1) harga dan penyebarannya di tingkat produsen dan konsumen; dan (2) marjin dan penyebarannya pada setiap pelaku pemasaran.

\section{Marjin Pemasaran}

Limbong dan Sitorus (1987), mendefinisikan marjin pemasaran sebagai perbedaan harga yang dibayar konsumen dengan harga yang diterima produsen, dan dapat disebut sebagai nilai dari jasa-jasa pelaksanaan kegiatan pemasaran mulai dari produsen sampai ke konsumen akhir. Marjin pemasaran pada umumnya dianalisis pada komoditi yang sama, jumlah yang sama dan pada pasar persaingan sempurna. Sedangkan menurut Dahl and Hammond (1977), marjin pemasaran adalah perbedaan harga antara harga di tingkat petani (Pf) dengan harga di tingkat pengecer (Pr), dimana marjin pemasaran tersebut ditunjukkan oleh perbedaan atau jarak vertikal antara kurva permintaan atau kurva penawaran.

Marjin pemasaran terdiri dari dua komponen, yaitu biaya pemasaran dan keuntungan pemasaran. Biaya pemasaran adalah semua jenis biaya yang dikeluarkan oleh lembaga-lembaga yang terlibat pada sistem pemasaran suatu komoditi dalam proses penyampaian barang dari produsen sampai ke konsumen akhir (misalnya : biaya tenaga kerja, biaya transportasi, biaya pungutan liar, biaya penyusutan, biaya sewa tempat usaha dll). Sedangkan keuntungan pemasaran adalah pengurangan marjin pemasaran dengan biayabiaya pemasaran.

Menurut Azzaino dalam Rediansyah (2003), marjin pemasaran adalah perbedaan harga yang dibayar oleh konsumen akhir untuk suatu produk dan harga yang diterima petani produsen untuk produk yang sama. Marjin pemasaran termasuk semua biaya yang menggerakkan produk tersebut, mulai dari petani sampai di pihak konsumen. Sehingga konsep marjin pemasaran dapat menjelaskan bahwa kegiatan pemasaran merupakan suatu kegiatan dalam menciptakan tambahan nilai (value added) baik nilai tempat, waktu, bentuk maupun hak milik melalui proses keseimbangan supply dan demand oleh pedagang yang berfungsi sebagai perantara antara petani (produsen) dengan konsumen akhir. 


\section{Farmer's Share}

Marjin pemasaran bukanlah satusatunya indikator yang menentukan efisiensi pemasaran suatu komoditas. Salah satu indikator lain adalah dengan membandingkan harga yang dibayar oleh konsumen akhir atau yang biasa disebut dengan farmer's share (bagian harga yang diterima petani), dan sering dinyatakan dalam persen. Farmer's share mempunyai hubungan yang negatif dengan marjin pemasaran, sehingga semakin tinggi marjin pemasaran maka bagian yang akan diperoleh petani akan semakin rendah.disebut dengan farmer's share (bagian harga yang diterima petani), dan sering dinyatakan dalam persen. Farmer's share mempunyai hubungan yang negatif dengan marjin pemasaran, sehingga semakin tinggi marjin pemasaran maka bagian yang akan diperoleh petani akan semakin rendah.

Farmer's share (bagian harga yang diterima petani) adalah perbandingan antara harga yang diterima petani dengan harga yang dibayar oleh konsumen akhir (Limbong dan Sitorus, 1987). Sedangkan Kohls and Uhls (1985) mendefinisikan farmer's share sebagai selisih antara harga retail dengan marjin pemasaran. Farmer's share merupakan bagian dari harga konsumen yang diterima oleh petani, dan dinyatakan dalam persentase harga konsumen. Hal ini berguna untuk mengetahui porsi harga yang berlaku di tingkat konsumen dinikmati oleh petani. Besar farmer's share biasanya dipengaruhi oleh: (1) tingkat pemrosesan; (2) biaya transportasi;

keawetan produk; dan (4) jumlah produk.

\section{Rasio Keuntungan Biaya}

Penyebaran marjin pemasaran talas dapat juga dilihat berdasarkan persentase keuntungan terhadap biaya pemasaran pada masing-masing lembaga pemasaran. Dengan demikian, untuk mengetahui apakah kegiatan pemasaran yang dilakukan memberikan keuntungan kepada pelaku pemasaran, maka digunakan analisis keuntungan per biaya.

\section{METODE PENELITIAN}

\section{Metode Pengumpulan Data}

Data yang digunakan dalam penelitian ini adalah data primer dan data sekunder. Data primer diperoleh melalui hasil pengamatan langsung di lapangan dan wawancara secara mendalam (indepth) dengan menggunakan daftar pertanyaan (kuisioner) yang telah disiapkan sebelumnya kepada lembaga-lembaga pemasaran/distribusi pangan, yaitu; produsen responden (petani) dan pedagang responden (pedagang pengumpul desa, pedagang besar (grosir atau wholesaler), importir, pedagang antar pulau dan pedagang pengecer). Data sekunder diperoleh melalui literatur pada berbagai lembaga/instansi yang terkait. Petani dan peternak responden berasal dari sentra produksi utama.

\section{Metode Penarikan Sampel}

Penentuan responden pada penelitian ini dilakukan dengan metode purposive sampling dan metode snowbow dari responden kunci (key pearson) dari setiap lembaga pemasaran baik di tingkat provinsi maupun di tingkat kabupaten/kota.

\section{Metode Pengolahan dan Analisis Data}

Pengolahan dan analisis data yang diperoleh dari data primer dan data sekunder dilakukan secara kuantitatif dan kualitatif. Analisis secara kuantitatif dilakukan untuk menghitung keragaan pasar melalui marjin pemasaran, farmer's Share dan rasio keuntungan biaya dengan mempergunakan bantuan kalkulator dan program Microsoft Excel.

Berdasarkan hasil dari analisis tersebut, kemudian diintepretasikan secara deskriptif dalam pembahasan yang meliputih analisis saluran dan lembaga pemasaran, analisis fungsi-fungsi pemasaran, dan analisis keragaan pasar.

\section{Waktu Penelitian}

Waktu pelaksanaan survei adalalah Juli 2012. 


\section{HASIL DAN PEMBAHASAN}

\section{Distribusi}

\section{Beras Giling}

Distribusi atau pemasaran beras giling sebagian besar masih dikuasai oleh pedagang pengumpul desa yang pada umumnya merupakan pemilik gilingan padi di desa. Hal ini terutama disebabkan oleh adanya keterbatasan modal yang dimiliki petani.

Berdasarkan hasil penelitian, diketahui bahwa distribusi beras giling di Kabupaten kepulauan Talaud hanya satu pola yang melibatkan beberapa lembaga pemasaran, yaitu pedagang pengumpul desa, pedagang besar di kota Manado dan pedagang pengecer di kota Lirung Kabupaten Kepulauan Talaud.

\section{Beras Kemasan Surabaya}

Beras kemasanan yang dipasarkan di pasar utama Kabupaten Kepulauan Talaud, yaitu di pasar Lirung adalah beras dari pusat perdagangan Surabaya. Distributor di kota Manado mendapat pasokan dari distributor di Kota Surabaya. Barang diterima di pelabuhan Samudera Bitung.

Hasil penelitian menunjukkan bahwa distribusi beras kemasan di Kabupaten kepulauan Talaud juga hanya satu pola yang melibatkan beberapa lembaga pemasaran, yaitu distributor di kota Manado, pedagang besar di kota Manado dan pedagang pengecer di kota Lirung Kabupaten Kepulauan Talaud.

\section{Margin Pemasaran}

Marjin pemasaran merupakan perbedaan harga atau selisih harga yang dibayar konsumen akhir dengan harga yang diterima produsen. Marjin pemasaran terdiri dari dua komponen, yaitu biaya pemasaran dan keuntungan pemasaran. Biaya pemasaran adalah semua jenis biaya yang dikeluarkan oleh lembagalembaga pemasaran, diantaranya yaitu; biaya transportasi, biaya bongkar muat, biaya pungutan liar, biaya akomodasi dan penyusutan, biaya retribusi dan biaya-biaya yang lainnya. Sedangkan keuntungan pemasaran adalah pengurangan antara marjin pemasaran dengan biaya-biaya pemasaran. Sebaran marjin pemasaran setiap bahan pokok pangan di setiap kabupaten kota di Provinsi Sulawesi Utara dapat dilihat pada tabel-tabel berikut.

Tabel 1. Sebaran Harga Rata-rata dan Margin Pemasaran Beras Giling di Kabupaten Kepulauan Talaud

\begin{tabular}{|l|r|r|}
\hline \multicolumn{1}{|c|}{ Unsur Margin } & \multicolumn{1}{c|}{$\begin{array}{c}\text { Nilai } \\
\text { (Rp/kg) }\end{array}$} & \multicolumn{1}{c|}{$\begin{array}{c}\text { Persen } \\
(\%)\end{array}$} \\
\hline $\begin{array}{l}\text { Petani di Kab. } \\
\text { Bolaang Mongondow }\end{array}$ & & \\
\hline Harga Jual & 7.000 & 73,68 \\
\hline $\begin{array}{l}\text { Pedagang Pengumpul } \\
\text { Desa }\end{array}$ & & \\
\hline Harga Beli & 7.000 & 73,68 \\
\hline Biaya Pemasaran & 67 & 0,70 \\
\hline Keuntungan & 1.100 & 11,58 \\
\hline Harga Jual & 8.167 & 85,96 \\
\hline Margin & 1.167 & 12,28 \\
\hline $\begin{array}{l}\text { Rasio Keuntungan } \\
\text { Biaya }\end{array}$ & 16,50 & \\
\hline $\begin{array}{l}\text { Pedagang Besar di } \\
\text { Kota Manado }\end{array}$ & & \\
\hline Harga Beli & 8.167 & 85,96 \\
\hline Biaya Pemasaran & 117 & 1,23 \\
\hline Keuntungan & 217 & 2,28 \\
\hline Harga Jual & 8.500 & 89,47 \\
\hline Margin & 333 & 3,51 \\
\hline Rasio Keuntungan Biaya & 1,86 & \\
\hline $\begin{array}{l}\text { Pedagang Pengecer di } \\
\text { Lirung }\end{array}$ & & \\
\hline Harga Beli & & \\
\hline Biaya Pemasaran & 229 & 2,41 \\
\hline Keuntungan & 2.500 & 100,00 \\
\hline Harga Jual & & 10,53 \\
\hline Margin & & \\
\hline Rasio Keuntungan Biaya & & \\
\hline Biaya Pemasaran Total & & \\
\hline Keuntungan Total & & \\
\hline Marjin Pemasaran Total & & \\
\hline Rasio Keuntungan Biaya & & \\
\hline
\end{tabular}




\section{Beras Giling}

Total marjin pemasaran yang terbentuk pada pola saluran distribusi bahan pokok pangan beras di Kabupaten Kepulauan Talaud adalah sebesar Rp 2500,00 per kg, dengan total biaya pemasaran sebesar Rp413 per kg.

Margin pemasaran tertinggi diperoleh oleh lembaga pemasaran pedagang pengumpul desa, yaitu sebesar Rp1.167 per kg, sedangkan pedagang pengumpul di Kota Manado dan pedagang pengecer di kota Lirung, masingmasing hamya memperoleh Rp333 per $\mathrm{kg}$ dan Rp1.000 per kg.

\section{Beras Kemasan dari Surabaya}

Total marjin pemasaran yang terbentuk pada pola saluran distribusi bahan pokok pangan beras di Kabupaten Kepulauan Talaud adalah sebesar Rp 3.500,00 per kg, dengan total biaya pemasaran sebesar Rp 454 per $\mathrm{kg}$.

Margin pemasaran tertinggi diperoleh oleh lembaga pemasaran pedagang pengecer di kota Lirung, yaitu sebesar Rp2.200 per kg, sedangkan distributor di Kota Manado dan pedagang besar di Kota Manado, masingmasing hanya memperoleh Rp500 per $\mathrm{kg}$ dan Rp800 per kg.

\section{Farmer's Share}

Farmer's share merupakan perbandingan antara harga yang diterima oleh petani dengan harga yang dibayarkan oleh konsumen, dan umumnya dinyatakan dalam persentase. Farmer's share ini merupakan sebagai konsep balas jasa atas kegiatan yang dilakukan petani dalam usahatani. Perhitungan farmer's share dilakukan terhadap bahan pokok pangan beras yang dihasilkan oleh petani di kabupaten kota di Provinsi Sulawesi Utara.

Besarnya farmer's share pada pemasaran beras giling di Kabupaten Kepulauan Talaud adalah sebesar 73,68\%, dimana harga di tingkat petani sebesar Rp7.000 per kg dan harga di tingkat konsumen sebesar Rp9.500 per kg.
Tabel 2. Sebaran Harga Rata-rata dan Margin Pemasaran Beras Kemasan di Kabupaten Kepulauan Talaud

\begin{tabular}{|l|r|r|}
\hline \multicolumn{1}{|c|}{ Unsur Margin } & \multicolumn{1}{c|}{$\begin{array}{c}\text { Nilai } \\
\text { (Rp/kg) }\end{array}$} & $\begin{array}{c}\text { Persen } \\
(\%)\end{array}$ \\
\hline $\begin{array}{l}\text { Distributor di Kota } \\
\text { Manado }\end{array}$ & & \\
\hline $\begin{array}{l}\text { Harga Beli (FOB } \\
\text { Bitung) }\end{array}$ & 7.500 & 68,18 \\
\hline Biaya Pemasaran & 108 & 0,98 \\
\hline Keuntungan & 392 & 3,56 \\
\hline Harga Jual & 8.000 & 72,73 \\
\hline Margin & 500 & 4,55 \\
\hline $\begin{array}{l}\text { Rasio Keuntungan } \\
\text { Biaya }\end{array}$ & 3,62 & \\
\hline $\begin{array}{l}\text { Pedagang Besar di } \\
\text { Kota Manado }\end{array}$ & 8.000 & 72,73 \\
\hline Harga Beli & 117 & 1,06 \\
\hline Biaya Pemasaran & 683 & 6,21 \\
\hline Keuntungan & 8.800 & 80,00 \\
\hline Harga Jual & 800 & 7,27 \\
\hline Margin & 5,86 & \\
\hline $\begin{array}{l}\text { Rasio Keuntungan } \\
\text { Biaya }\end{array}$ & 1.971 & 17,91 \\
\hline $\begin{array}{l}\text { Pedagang Pengecer di } \\
\text { Lirung }\end{array}$ & 2.200 & 100,00 \\
\hline Harga Beli & 8,800 & 80,00 \\
\hline Biaya Pemasaran & 6,70 & 2,00 \\
\hline Keuntungan & & \\
\hline Harga Jual & & \\
\hline Margin & & \\
\hline $\begin{array}{l}\text { Rasio Keuntungan } \\
\text { Biaya }\end{array}$ & & \\
\hline Biaya Pemasaran Total & & \\
\hline Keuntungan Total & & \\
\hline Marjin Pemasaran Total & & \\
\hline Rasio Keuntungan Biaya & & \\
\hline & & \\
\hline
\end{tabular}

\section{Rasio Keuntungan Biaya \\ Beras Giling \\ Rasio keuntungan biaya pada setiap lembaga pemasaran bahan pokok pangan beras giling di Kabupaten Kepulauan Talaud dapat dilihat pada Tabel 75. Berdasarkan Tabel 75}


Tabel 3. Rasio Keuntungan Biaya Lembaga Pemasaran Beras Giling di Kabupaten Kepulauan Talaud

\begin{tabular}{|l|r|r|r|}
\hline $\begin{array}{l}\text { Lembaga } \\
\text { Pemasaran }\end{array}$ & $\begin{array}{c}\text { Keun- } \\
\text { tungan } \\
\text { (Rp/kg) }\end{array}$ & $\begin{array}{c}\text { Biaya } \\
(\mathrm{Rp} / \mathrm{kg})\end{array}$ & $\begin{array}{c}\text { Rasio } \\
\text { Keun- } \\
\text { tungan } \\
\text { Biaya }\end{array}$ \\
\hline $\begin{array}{l}\text { Pedagang } \\
\text { Pengumpul } \\
\text { Desa }\end{array}$ & 1.100 & 67 & 16,50 \\
\hline $\begin{array}{l}\text { Pedagang } \\
\text { Besar di } \\
\text { Kota } \\
\text { Manado }\end{array}$ & 217 & 117 & 1,86 \\
\hline $\begin{array}{l}\text { Pedagang } \\
\text { Pengecer di } \\
\text { Lirung }\end{array}$ & 771 & 229 & 3,36 \\
\hline
\end{tabular}

terlihat bahwa rasio keuntungan biaya pada lembaga pemasaran pedagang pengumpul desa sangat besar dibandingkan pada pedagang pengumpul di Kota Manado dan pedagang pengecer di Kota Lirung. Rasio keuntungan biaya terendah terjadi pada lembaga pemasaran pedagang besar di Kota Manado.

\section{Beras Kemasan dari Surabaya}

Rasio keuntungan biaya pada setiap lembaga pemasaran bahan pokok pangan beras giling di Kabupaten Kepulauan Talaud dapat dilihat pada Tabel 76. Berdasarkan Tabel 76 terlihat bahwa rasio keuntungan biaya pada lembaga pemasaran pedagang pengumpul desa sangat besar dibandingkan pada pedagang pengumpul di Kota Manado dan pedagang pengecer di Kota Lirung. Rasio keuntungan biaya terendah terjadi pada lembaga pemasaran pedagang besar di Kota Manado.
Tabel 4. Rasio Keuntungan Biaya Lembaga Pemasaran Beras Kemasan di Kabupaten Kepulauan Talaud

\begin{tabular}{|l|r|r|r|}
\hline $\begin{array}{l}\text { Lembaga } \\
\text { Pemasaran }\end{array}$ & $\begin{array}{c}\text { Keun- } \\
\text { tungan } \\
(\mathrm{Rp} / \mathrm{kg})\end{array}$ & $\begin{array}{c}\text { Biaya } \\
(\mathrm{Rp} / \mathrm{kg})\end{array}$ & $\begin{array}{r}\text { Rasio } \\
\text { Keun- } \\
\text { tungan } \\
\text { Biaya }\end{array}$ \\
\hline $\begin{array}{l}\text { Distributor } \\
\text { di Kota } \\
\text { Manado }\end{array}$ & 392 & 108 & 3,62 \\
\hline $\begin{array}{l}\text { Pedagang } \\
\text { Besar di } \\
\text { Kota } \\
\text { Manado }\end{array}$ & 683 & 117 & 5,86 \\
\hline $\begin{array}{l}\text { Pedagang } \\
\text { Pengecer di } \\
\text { Lirung }\end{array}$ & 1.971 & 229 & 8,59 \\
\hline
\end{tabular}

\section{KESIMPULAN}

1. Distribusi beras kemasan di Kabupaten kepulauan Talaud juga hanya satu pola yang melibatkan beberapa lembaga pemasaran, yaitu distributor di kota Mananado, pedagang besar di kota Manado dan pedagang pengecer di kota Lirung Kabupaten Kepulauan Talaud.

2. Ddistribusi beras giling di Kabupaten kepulauan Talaud hanya satu pola yang melibatkan beberapa lembaga pemasaran, yaitu pedagang pengumpul desa, pedagang besar di kota Manado dan pedagang pengecer di kota Lirung Kabupaten Kepulauan Talaud.

3. Total marjin pemasaran yang terbentuk pada pola saluran distribusi bahan pokok pangan beras giling di Kabupaten Kepulauan Talaud adalah sebesar $\mathrm{Rp}$ 2500,00 per $\mathrm{kg}$, dengan total biaya pemasaran sebesar Rp413 per kg. 
4. Total marjin pemasaran yang terbentuk pada pola saluran distribusi bahan pokok pangan beras krmasan di Kabupaten Kepulauan Talaud adalah sebesar $\mathrm{Rp}$ 3.500,00 per $\mathrm{kg}$, dengan total biaya pemasaran sebesar Rp 454 per $\mathrm{kg}$.

5. Besarnya farmer's share pada pemasaran beras giling di Kabupaten Kepulauan Talaud adalah sebesar $73,68 \%$, dimana harga di tingkat petani sebesar Rp7.000 per $\mathrm{kg}$ dan harga di tingkat konsumen sebesar Rp9.500 per kg.

6. Rasio keuntungan biaya pada lembaga pemasaran pedagang pengumpul desa sangat besar dibandingkan pada pedagang pengumpul di Kota Manado dan pedagang pengecer di Kota Lirung. Rasio keuntungan biaya terendah terjadi pada lembaga pemasaran pedagang besar di Kota Manado.

\section{DAFTAR PUSTAKA}

Dahl, D.C. and J.W. Hammond. 1977. Market and Price Analysis The Agricultural Industries. McGraw-Hill Book Company. New York.

Kohls, R.L. and J.N. Uhl. 1985. Marketing Of Agricultural Products. MacMillian Publishing Company. New York.
Kotler. 2002. Manajemen Pemasaran. Edisi kesepuluh. PT Prenhallindo. Jakarta.

Kotler. 2002. Manajemen Pemasaran. Edisi kesebelas. PT Prenhallindo. Jakarta.

Limbong dan Sitorus. 1987. Pengantar Tataniaga Pertanian (diktat kuliah) Edisi 1. Jurusan Ilmu-ilmu Sosial Ekonomi Pertanian. Fakultas Pertanian. IPB. Bogor.

Pakpahan. 2006. Analisis sistem Pemasaran Manggis (Kasus di Desa Babakan, Kecamatan Wanayasa, Kabupaten Purwakarta, dan di Desa Karacak, Kecamatan Leuwiliang, Kabupaten Bogor, Jawa Barat). Skripsi. Program Studi Manajemen Agribisnis. Fakultas Pertanian. IPB. Bogor.

Rediansyah. 2003. Analisis Sistem Pemasaran Bawang Daun (Kasus di Desa Cijarian Pandai Kecamatan Kadudampit Kabupaten Sukabumi). Skripsi. Departemen Ilmu-ilmu Sosial Ekonomi Pertanian. Fakultas Pertanian. IPB. Bogor.

Said dan Intan. 2004. Manajemen Agribisnis. PT Ghalia Indonesia. Jakarta.

Sudiyono. 2002. Pemasaran Pertanian. Universitas Muhammadiyah. Malang. 